\title{
TERMOELEKTROMOS ANYAGOK ÉS ESZKÖZÖK A FENNTARTHATÓ JÖVŐÉRT
}

\section{THERMOELECTRIC MATERIALS AND DEVICES FOR A SUSTAINABLE FUTURE}

\author{
Edgar Marcial Pimentel ${ }^{1}$, István Nagy ${ }^{2}$ \\ Óbuda University, Donát Bánki Faculty of Mechanical and Safety Engineering, \\ Hungary, Budapest, Népszínház Utca, 8. \\ ${ }^{1}$ Tel:+36-70-222-77-11,edgarmar.pimsev@gmail.com \\ ${ }^{2}$ Tel.: +36-1-666-53-66, nagy.istvan@bgk.uni-obuda.hu
}

\begin{abstract}
About $30 \%$ of the energy produced by fuels, and used for automotive industry, is actually generating movement, letting the rest of it to get lost as dissipation in friction and heat. This is just one of the multiple systems that generate waste heat energy. These statements serve as a base to understand and justify the important role of research and development of new green materials and technologies. This paper provides a general context on the current and potential future panorama of these materials and their applications, also providing the reader with the essentials for understanding the content.
\end{abstract}

Keywords: Thermoelectric Materials, Household and Industrial Applications, Mechatronics in Environmental Sustainability.

\section{Összefoglalás}

A gépjárművekben kitermelt energiának nagyjából 30\%-a kerül mozgás általi felhasználásra, a többi energia mind veszteségként (hő, súrlódás, etc..) elveszik a környezetben. Ezen tény, és a napjainkban állandóan megújuló technológiák alapján meg kell vizsgálni annak a lehetőségét, hogy lehetne ezt az „elpazarolt” disszipált hömennyiséget, hasznos villamos energiává alakítani oly módon, hogy ezzel elősegítsük a „hibrid” autók villamos energiatermelését. Ebben a konferenciacikkben olyan anyagok gyártását mutatjuk be, melyek elősegíthetnék ezt a folyamatot. Arra szeretnénk rámutatni, hogy a termo-elektromos anyagok bővebb kihasználása lehetőséget adna az ilyen „elpazarolt” hőenergiák hasznosítására.

Kulcsszavak: Termo-elektromos anyagok, Termisztorok, Ipari alkalmazások, Mechatronika a fenntartható környezet érdekében, Energiahasznositás

\section{Introduction}

Energy generation and consumption has remained a constant topic of interest for most of the nations throughout the last decades. It is true that major improvements have been achieved within many fields of technology which has lead us to the devel- opment of green or echo-friendly technologies, which are one of the increasingly trending matters of study nowadays. Their importance and relevance is directly proportional to the fact that energy is present in every important process and many times it's being wasted as a side effect of them. 
Heat is the most common way of waste energy and it occurs not only in engineering or industrial processes, but to a household level as well; cars are the most clear and accessible example for it. Approximately $40 \%$ of the fuel energy is wasted in exhaust gas, $30 \%$ is dissipated in the engine coolant, $5 \%$ is lost as radiation and friction, and only $25 \%$ is used for vehicle mobility and accessories. [1]

With the previous statement, it could be inferred that from out of the nearly 3042.5 thousand barrels of gasoline consumed in Europe per day [2], only 760.6 are effectively producing motion.

The field of thermoelectrics require not only of ideas on applications but firstly the research and development of highly efficient thermoelectric materials.

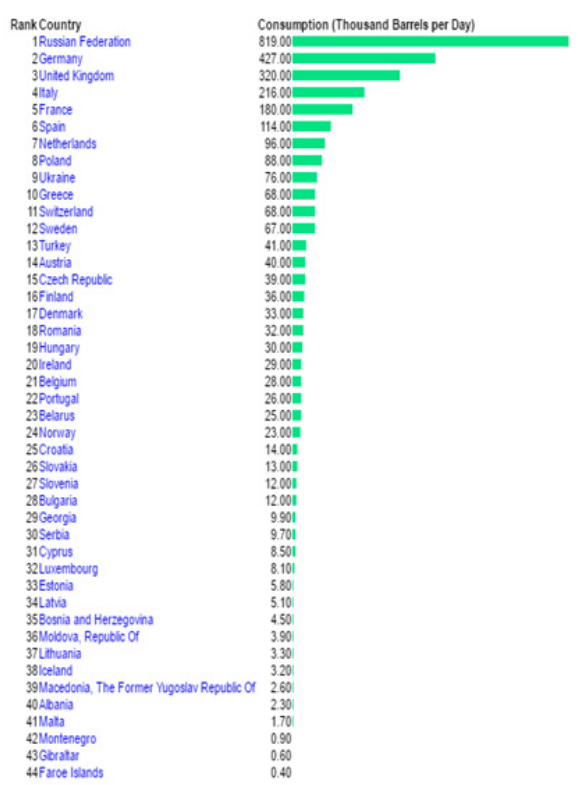

1. fig. Gasoline consumption in Europe, sorted by country (2012). [2]

\section{Background}

The basic physic principle upon which Termoelectric Generators (Further on
T.G.E.'S) are able to transfor heat energy into electricity is the Seebeck Effect.

This phenomenon was discovered in 1821 and the definition stated that a basic setup consisting of two different metallic elements with a common contact point could produce an electric current whenever a differential of temperature was applied at the ends of the materials. This was taken forward and scientist had been studying this property, which lead to the discovery that certain thermoelectric materials have good heat converstion properties. [1]

The parametric number that can define the efficiency of such materials used in the production of TGE's, is the so called Figure of Merit represented by:

$$
Z T=\frac{S^{2} T}{K \rho}=\frac{S^{2} T}{\left(K_{e}+K_{l}\right) \rho}
$$

where,

$\mathrm{S}=$ Seebeck Coefficient,

$\mathrm{K}=$ Thermal Conductivity,

$\rho=$ Electrical Conductivity

$\mathrm{T}=$ Absolute Temperature.

Usually, good thermoelectric materials are special types of Semiconductors.

Through the years, three main types of materials have been known thanks to the hard work of researchers, all though, the most complex and reliable ones haven't reached affordable production costs and therefore they are still not being produced in mass scale for important portential applications.

It is important to notice that the criteria that every good thermoelectric semiconductor material should meet are the following:

- To be heavily-doped semiconductors.

- The Energy of the Bandgap should be less than $1 \mathrm{eV}$.

- They should present a low Thermal Conductivity, whilst preserving a good electrical conductivity.

Next up, the main types (approaches) of these materials are briefly described. 


\subsection{Thermoelectric Bulk Materials}

The alloying of bulk materials is the most cost friendly option but the results aren't the best by this method since efficiency ZT from these materials isn't high enough for the desired applications for a future.

It could be said that one of the most well-known and efficient bulk thermoelectric materials is the $B i_{2} T e_{3}$. This material can generate a ZT value of around 1. [1]

\subsection{Thermoelectric Nano-Structured Materials}

One known approach to improve the ZT on thermoelectric bulk materials is the creation of PGEC, or Phonon Glass Electric Crystals. This idea has been applied to generate Sketerudites.

Despite the previous advancement, the most recent researches are trying to create Nano-Structured (or Engineered) Materials. The goal of this approach is to reduce the thermal conductivity of the material by modifying its Crystal Lattice.

The modifications to the composition of the material, consist in augmenting the thickness of the material layers so the mean free path in such a way that phonons are positioned in a distributed way. This will reduce effectively their mobility and therefore the thermal conductivity.

This approach deals with one and bidimensional sized nano-structures.

In the case of 2D, the most efficient example found to the day are the $B i_{2} T e_{3}-$ $\mathrm{Sb}_{2} \mathrm{Te}_{3}$ modified lattices. (This meaning that there are lattices embedded in the material with a certain thickness and periodicity). These materials have an improved ZT value of around the double of the bulk counterpart of it. $(\mathrm{ZT}=2.4 \mathrm{vs} . \mathrm{ZT}=1.1)$. [1]

\subsection{Thermoelectric Nano-Composite Materials}

Nano-Composites represent the latest improvements. These materials are embedded nano-modified structures into bulk materials, making it possible to custom reduce the phonon mean free path significantly, reducing the phonon transportation but without affecting the mobility of the charge carriers.

\begin{tabular}{|c|c|c|c|c|c|c|}
\hline Material systems & Carrier type & ZT & $\kappa_{L}\left[\mathrm{~W} \mathrm{~m}^{-1} \mathrm{~K}^{-1}\right]$ & $T$ & Synthetic method ${ }^{*}$ & Ref. \\
\hline \multicolumn{7}{|l|}{ PbTe-based nanocomposites } \\
\hline $\mathrm{AgPb}_{18} \mathrm{SbTe}_{20}$ & $\mathrm{n}$ & 2.2 & - & $800 \mathrm{~K}$ & NP & [16] \\
\hline $\mathrm{Ag}_{0.5} \mathrm{~Pb}_{6} \mathrm{Sn}_{2} \mathrm{Sb}_{0.2} \mathrm{Te}_{10}$ & $\mathrm{p}$ & 1.45 & 0.43 & $630 \mathrm{~K}$ & NP & [90] \\
\hline $\mathrm{Ag}_{0.53} \mathrm{~Pb}_{18} \mathrm{Sb}_{1.2} \mathrm{Te}_{20}$ & $\mathrm{n}$ & 1.7 & - & $700 \mathrm{~K}$ & NP & [91] \\
\hline $\mathrm{K}_{0.95} \mathrm{~Pb}_{20} \mathrm{Sb}_{1.2} \mathrm{Te}_{22}$ & $\mathrm{n}$ & 1.6 & 0.4 & $750 \mathrm{~K}$ & NP & [92] \\
\hline $\mathrm{Na}_{0.95} \mathrm{~Pb}_{20} \mathrm{SbTe}_{22}$ & $\mathrm{p}$ & 1.7 & 0.74 & $700 \mathrm{~K}$ & NP & [17] \\
\hline $\mathrm{PbTe}-\mathrm{PbS} 8 \%$ & $\mathrm{n}$ & 1.4 & - & $750 \mathrm{~K}$ & NP & [93] \\
\hline $\mathrm{PbTe}-\mathrm{Pb}-\mathrm{Sb}$ & $\mathrm{n}$ & 1.4 & 0.6 & $700 \mathrm{~K}$ & NP & [94] \\
\hline $\mathrm{PbTe}-\mathrm{Si}$ & $\mathrm{n}$ & 0.9 & - & $675 \mathrm{~K}$ & NP & [95] \\
\hline $\mathrm{Pb}_{9.6} \mathrm{Sb}_{0.2} \mathrm{Te}_{3} \mathrm{Se}_{7}$ & $\mathrm{n}$ & 1.2 & 0.4 & $650 \mathrm{~K}$ & NP & [97] \\
\hline$\left(\mathrm{Pb}_{0.95} \mathrm{Sn}_{0.05} \mathrm{Te}\right)_{0.92}(\mathrm{PbS})_{0.08}$ & $\mathrm{n}$ & 1.50 & 0.4 & $642 \mathrm{~K}$ & NP & [23] \\
\hline $2 \% \mathrm{SrTe}$-containing $\mathrm{PbTe}$ & $P$ & 1.7 & 0.45 & $800 \mathrm{~K}$ & NP & [100] \\
\hline $\mathrm{NaPb}_{18} \mathrm{BiTe}_{20}$ & $\mathrm{p}$ & 1.3 & - & $670 \mathrm{~K}$ & NP & [103] \\
\hline $\mathrm{Ag}_{0.8} \mathrm{~Pb}_{22 .} .5 \mathrm{SbTe}_{20}$ & $\mathrm{n}$ & 1.5 & 0.89 & $700 \mathrm{~K}$ & MA+SPS & [106] \\
\hline \multicolumn{7}{|l|}{ SiGe-based nanocomposites } \\
\hline $\mathrm{Si}_{80} \mathrm{Ge}_{20}$ & $\mathrm{p}$ & 0.95 & - & $1073 \mathrm{~K}$ & $\mathrm{HEBM}+\mathrm{HP}$ & [107] \\
\hline $\mathrm{Si}_{80} \mathrm{Ge}_{20} \mathrm{P}_{2}$ & $\mathrm{n}$ & 1.3 & & $1173 \mathrm{~K}$ & $\mathrm{HEBM}+\mathrm{HP}$ & [25] \\
\hline \multicolumn{7}{|l|}{ New thermoelectric materials } \\
\hline $\mathrm{In}_{4} \mathrm{Se}_{3-\delta}$ & $\mathrm{n}$ & 1.48 & - & $705 \mathrm{~K}$ & Bridgeman method & [26] \\
\hline $\mathrm{In}_{4} \mathrm{Se}_{3-x} \mathrm{Cl}_{0.03}$ & $\mathrm{n}$ & 1.53 & - & $698 \mathrm{~K}$ & Bridgeman method & [109] \\
\hline$\beta-\mathrm{Cu}_{2-x} \mathrm{Se}$ & $\mathrm{p}$ & 1.5 & 0.4 & $1000 \mathrm{~K}$ & MAG+SPS & [28] \\
\hline$\beta-\mathrm{Zn}_{4} \mathrm{Sb}_{3}$ & $\mathrm{p}$ & 1.35 & - & $673 \mathrm{~K}$ & Bridgeman method & [22] \\
\hline
\end{tabular}

2. fig. Properties of Advanced Thermoelectric Materials [1] 
This fulfils the third stablished condition for effective thermoelectric semiconductors, which states that the thermal conductivity should be reduced by the time the electrical conductivity is kept at a good level.The most important advancements were achieved while using PbTe based alloys; this record show a $\mathrm{ZT}$ value for approximately 2.2 , just followed by $B i_{2} T e_{3}$ based composites, which ZT's range goes from 1.4 to 1.7 .

Lastly, some improvements have been made also while implementing these nanomodification techniques on SiGe based materials with near 1.3 ZTs. [1]

As can be inferred from this data, the nano-composites are the best approach of high efficiency (high performance) thermoelectric materials, and therefore they become, theoretically speaking, a good option for the growing interest in the development of green technologies, however, their manufacture hasn't reached popularity in a big scale because of the complexity and the cost of the processes required for it.

\subsection{Current and Future Panorama}

As stated, the analysis and process of the nano-composite materials turns to be expensive and complex to make, and so, this has slowed down the process of applying these technologies for real life solutions.

Just recently in 2015, American enterprise ThermoAura emerged and began producing this kind of materials in a large scale after the discovery of an efficient production process implying the use of nano waving. Despite the medium size of this company, this could be seen as the first of many steps leading to a more ecologically conscious world.

This type of research could result in the application of new processes worldwide that can provide with cost-friendly solutions for generating these materials.
Main potential applications include (but are not limited to) the design of new automotive cooling systems embedded in Hybrid Electric Vehicles that include TEG devices to recover the waste energy from the main engine (internal combustion) and can re-inject the recovered energy in the form of electricity into the HEV system, similarly to the way the Kinetic Energy Recovery Systems work; please note that this application might be useful in current scenarios, where the main fuel is still fossilbased, and future potential scenarios where bio-fuels can be integrated as an alternative for combustion engines. Also, another seemingly important application, could be the integration to these devices in industrial processes such as steel production, could help save energy and eventually be part of the list of actions to reduce the conventional fuel dependency. Not to mention other household possible applications for daily life solutions.

\section{Conclusion}

Thermoelectric materials should be a must in the list of interests of the governments and research departments worldwide, due to the potential applications they have. Also, it is important to take into account that the integration of multiple green energy sources into new technologies can improve the performance of such devices.

\section{Bibliography:}

[1] Zhi-Gang C.;Guang H.; Lei Y.; Lina C.; Jin Z: Nanostructured Thermoelectric Materials: Current Research and Future Challenge. Progress in Natural Science: Materials International 22, 2012, 535-549.

[2] Index Mundi: Motor Gasoline Consumption by Country. 2012. 